\title{
LXVIII. Comparison between the chords of arcs employed by Ptolemy and those now in use
}

\section{G.A. Walker Arnott A.M.}

To cite this article: G.A. Walker Arnott A.M. (1818) LXVIII. Comparison between the chords of arcs employed by Ptolemy and those now in use , Philosophical Magazine Series 1, 52:248, 454-456, DOI: $10.1080 / 14786441808652078$

To link to this article: http://dx.doi.org/10.1080/14786441808652078

册 Published online: 23 Jul 2009.

Submit your article to this journal $\sqsubset \pi$

Џll Article views: 2

Q View related articles 두 
Institution, in which it has been twice carefully distilled at a low heat, it has still contained minute quantities of phosphorus.

It has been supposed that dry phosphoric acid is fixed at a white heat; but I find that this is rot the case: it rapidly rises in vapour at this temperature, and evaporates even at the point of fusion of flint glass: and the hydrate of phosphoric acid is susceptible of being volatilized at a much lower temperature.

In converting the solid sublimate composed of phosphorus and chlorine into the liquid compound, when the phosphorus is first used in contact with the sublimate, a yellow crystalline mass is formed, which, when acted on by a higher degree of heat, affords the liquid chloride, which rises from it in vapour, and leaves phosphorus behind. It is possible that this yellow solid is a compound of phosphorus and chlorine, containing half as much chlorine as the liquid. Should this be proved to be the case by future exeriments, it will give weight to the idea, that the hypophosphorous acid is a binary compound of oxygen and phosphorus.

LXVIII. Comparison letween the Chords of Arcs employed by Ptolemy and those now in Use. By G. A. Walker Arnotr, A.M. Edinburgh.

To Mr. Tilloch.
SIR, $-\mathrm{I}_{\mathrm{N}}$ a late elegant publication (The Philosophy of Arithmetic), it is stated that the ratio of 1 to $3 \cdot 1416$, or of the diameter to the circumference of a circle, must have been almost known to Claudius Ptolemy. This celebrated philosopher and mathematician, and first of ancient astronomers, left behind him, in the third book of his Almagest, a table of the chords of the ares of the circle, calculated in sexagesimals to every 30 or half degree, and which are found to coincide with those in the trigonometrical tables we at present employ, with a much more considerable degree of exactness than could reasonably be looked for from the small advances made at that time in this subject. It is therefore my purpose here to exhibit a table of comparison between these, the insertion of which in your Magazine may gratify such of the curious as may not have seen the work itself of this distinguished man.

The first column contains the chords of every two degrees.of the semicircle, as calculated by Ptolemy in sexagesimals. In the second column are the same chords converted into sexagesimals from our common decimal tables: and here I may add, that that number is taken, nearest to which, either above or below, the true number approaches, when extended to thirds, fourths, \&c. of the radius. In the third are Ptolemy's calculations turned into decimals; and in the fourth we have an ex- 
tract from the trigonometrical tables now in use.-Before inserting the table, we may borrow the following example for the purpose of showing how near Ptolemy approached to our eustomary ratio of $1: 3 \cdot 1416$ : the chord of $2^{\circ}$ in sexagesimals to radius $\xi$ or $60^{\circ}$ is $\beta \varepsilon \mu$, or $2^{\circ} 5^{\prime} 40^{\prime \prime}$, which in decimals is liearly .034907 to radius 1 , and this multiplied by $\frac{180^{\circ}}{2^{\circ}}=90$ gives $3 \cdot 1416$ nearly : now as the chord of $2^{\circ}$ is almost the measure of its arc, the above number may be taken as the length of the semicircumference.

Edinburgh, 12th November 1818.

\begin{tabular}{|c|c|c|c|c|}
\hline $2^{0}$ & $2^{\circ} 5^{\prime} 40^{\prime \prime}$ & $2^{0} 5^{\prime} 39 \frac{\frac{1}{2}}{2}$ & .0349074 & .0349048 \\
\hline 4 & 41116 & $411116 \frac{1}{2}$ & $\cdot 0697963$ & $\cdot 0697990$ \\
\hline 6 & 61649 & 61649 & $\cdot 1046713$ & $\cdot 1046720$ \\
\hline 8 & 82215 & 82215 & $\cdot 1395139$ & $\cdot 1395130$ \\
\hline 10 & 102732 & 102731 & $\cdot 1743 ! 48$ & $\cdot 1743114$ \\
\hline 12 & 123236 & 123236 & $\cdot 20 g 0555$ & 2090570 \\
\hline 14 & $1437 \quad 27$ & $143727 \frac{1}{2}$ & $\cdot 2437361$ & ${ }^{2} 2437386$ \\
\hline 16 & $1642 \quad 3$ & 16423 & 3472 & -2783462 \\
\hline 18 & $\begin{array}{lll}18 & 46 & 19\end{array}$ & 184620 & 8657 & 3128090 \\
\hline 20 & 205016 & $\begin{array}{lll}20 & 50 & 16\end{array}$ & 2063 & $\cdot 3472904$ \\
\hline 22 & $\begin{array}{lll}22 & 53 & 49\end{array}$ & $225349 \frac{I}{2}$ & 157 & $\cdot 3816180$ \\
\hline 24 & 245658 & 245658 & 261 & $\cdot 4158234$ \\
\hline 26 & 265938 & $\begin{array}{lll}26 & 59 & 39\end{array}$ & 981 & $02 \leq$ \\
\hline 28 & $29 \quad 150$ & 29150 & 426 & 438 \\
\hline 30 & $\begin{array}{lll}31 & 3 & 30\end{array}$ & 31330 & 389 & 380 \\
\hline 32 & 33435 & 435 & 731 & .5512748 \\
\hline 34 & $\begin{array}{lll}35 & 5 & 5\end{array}$ & $\begin{array}{lll}35 & 5 & 4 \frac{1}{2}\end{array}$ & 454 & .5847434 \\
\hline 36 & 37455 & 37455 & $\cdot 6180324$ & 340 \\
\hline 38 & $\begin{array}{lll}39 & 4 & 5\end{array}$ & $39 \quad 4 \quad 5 \frac{I}{2}$ & 343 & 364 \\
\hline 40 & 41233 & 41233 & $\cdot 6840417$ & $\cdot 6840402$ \\
\hline 42 & $43 \quad 0 \quad 15$ & 43015 & .7167361 & 7167358 \\
\hline 44 & $\begin{array}{lll}44 & 57 & 10\end{array}$ & $44 \quad 57 \quad 10$ & 2130 & .7492132 \\
\hline 46 & $46 \quad 53 \quad 16$ & $4653 \quad 16$ & 7814630 & $\because 814622$ \\
\hline 48 & $48 \quad 48 \quad 30$ & $48 \quad 48 \quad 30$ & 8134722 & $\cdot 8134732$ \\
\hline 50 & 504251 & 504251 & $\cdot 8452361$ & $\cdot 8452366$ \\
\hline 52 & $\begin{array}{lll}52 & 36 & 16\end{array}$ & $\begin{array}{llll}52 & 36 & 16\end{array}$ & $\cdot 8767407$ & $\cdot 8767422$ \\
\hline 54 & $54 \quad 28 \quad 44$ & $54 \quad 2844$ & 9079815 & $\cdot 9079810$ \\
\hline 56 & $56 \quad 2012$ & $\begin{array}{lll}56 & 20 & 12\end{array}$ & 9389444 & 0389432 \\
\hline 58 & $\begin{array}{lll}58 & 10 & 38\end{array}$ & $58 \quad 1038$ & $\cdot 9696204$ & $969619^{2}$ \\
\hline 60 & $\begin{array}{lll}60 & 0 & 0\end{array}$ & $60 \bigcirc 0$ & $1 \cdot 0000000$ & 1.0000000 \\
\hline 62 & $\begin{array}{lll}61 & 48 & 17\end{array}$ & $614816 \frac{1}{2}$ & 1.0300787 & 1.0300762 \\
\hline 64 & $\begin{array}{lll}63 & 35 & 26\end{array}$ & 633525 & $1^{\circ} 0598426$ & 10598386 \\
\hline 66 & 652124 & $\begin{array}{lll}65 & 21 & 24\end{array}$ & 1.0892778 & 1.0892780 \\
\hline 68 & $67 \quad 6 \quad 12$ & $67 \quad 6 \quad 11$ & $1 \cdot 1183889$ & $1 \cdot 1183858$ \\
\hline 70 & 684945 & 684945 & $1 \cdot 1471528$ & $1 \cdot 1471528$ \\
\hline 72 & $7032 \quad 3$ & $7032 \quad 3$ & $1 \cdot 1755694$ & $1 \cdot 1755706$ \\
\hline 74 & $\begin{array}{lll}72 & 13 & 4\end{array}$ & $\begin{array}{lll}72 & 13 & 4\end{array}$ & $1 \cdot 2036296$ & $1 \cdot 2036300$ \\
\hline 76 & 735246 & $73 \quad 5246$ & $1 \cdot 2313061$ & 1.2313230 \\
\hline 78 & 75317 & $7531 \quad 6 \frac{x}{2}$ & $1 \cdot 2586435$ & $1 \cdot 2586408$ \\
\hline
\end{tabular}


D.

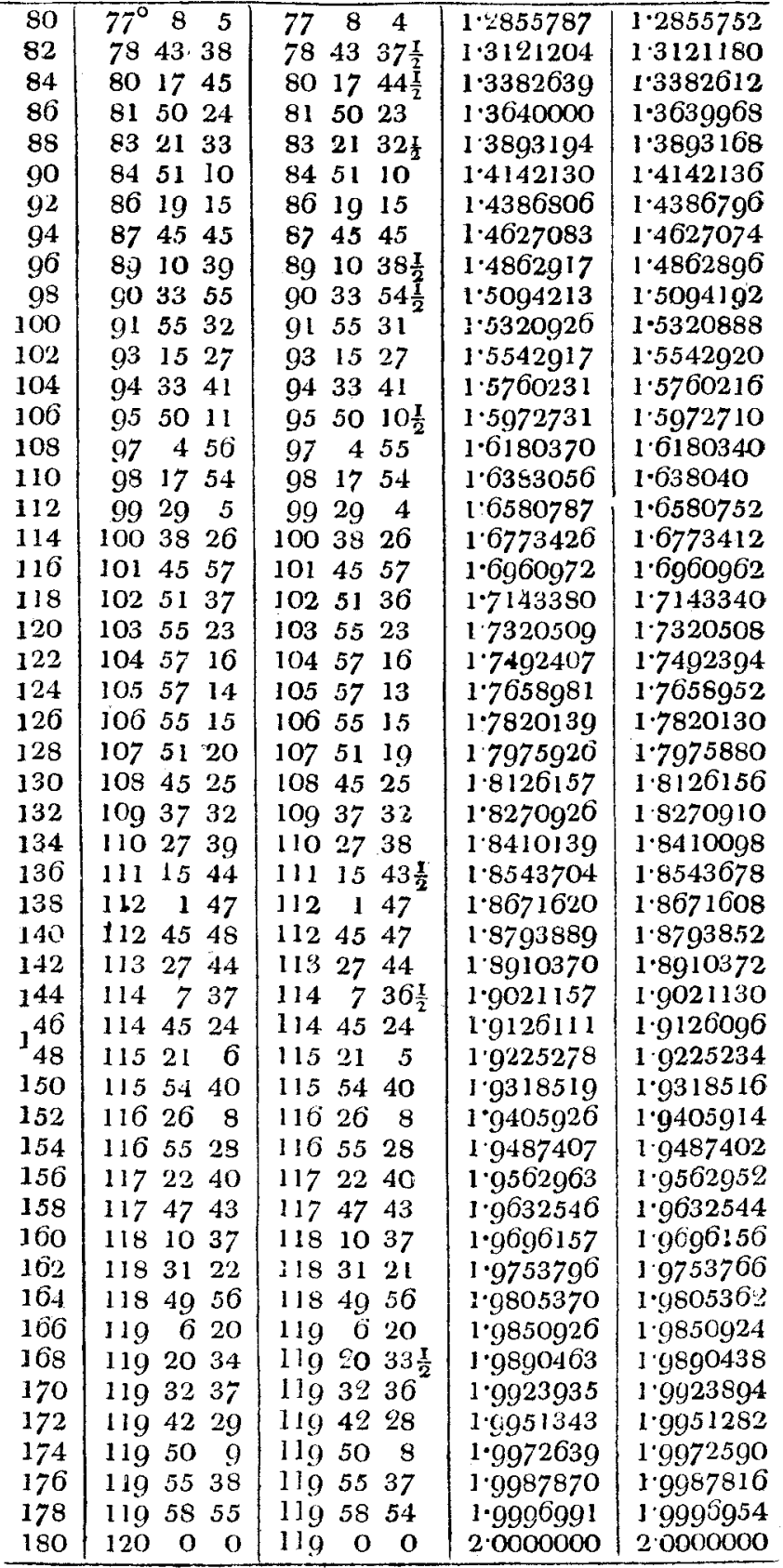

